\title{
Purinergic mechanisms in the control of gastrointestinal motility
}

\author{
J. C. Bornstein
}

Received: 9 May 2007 / Accepted: 6 September 2007 / Published online: 6 October 2007

(C) Springer Science + Business Media B.V. 2007

\begin{abstract}
For many years, ATP and adenosine have been implicated in movement regulation of the gastrointestinal tract. They act through three major receptor subtypes: adenosine or $\mathrm{P} 1$ receptors, $\mathrm{P} 2 \mathrm{X}$ receptors and $\mathrm{P} 2 \mathrm{Y}$ receptors. Each of these major receptor types can be subdivided into several different classes and is widely distributed amongst various neurons, muscle types, glia and interstitial cells that regulate intestinal functions. Several key roles for the different receptors and their endogenous ligands have been identified in physiological and pharmacological studies. For example, adenosine acting at $\mathrm{A}_{1}$ receptors appears to inhibit intestinal motility in various pathological conditions. Similarly, ATP acting at P2Y receptors is an important component of inhibitory neuromuscular transmission, acting as a cotransmitter with nitric oxide. ATP acting at $\mathrm{P} 2 \mathrm{X}$ and $\mathrm{P}_{2} \mathrm{Y}_{1}$ receptors is important for synaptic transmission in simple descending excitatory and inhibitory reflex pathways. Some P2Y receptor subtypes prefer uridine nucleotides over purine nucleotides. Thus, roles for UTP and UDP as enteric transmitters in place of ATP cannot be excluded. ATP also appears to be important for sensory transduction, especially in chemosensitive pathways that initiate local inhibitory reflexes. Despite this evidence, data are lacking about the roles of either adenosine or ATP in more complex motility patterns such as segmentation or the interdigestive migrating motor complex. Clarification of roles for purinergic transmission in these common, but understudied, motility patterns will depend on the use of subtype-specific antagonists that in some cases have not yet been developed.
\end{abstract}

J. C. Bornstein $(\bowtie)$

Department of Physiology, University of Melbourne,

Parkville, VIC 3010, Australia

e-mail: j.bornstein@unimelb.edu.au
Keywords Enteric nervous system · Smooth muscle Synaptic transmission - Adenosine - ATP P P2X · P2Y . Intestinal motility

\section{Introduction}

Purine nucleosides and nucleotides have long been thought to play important roles as signalling molecules in the complex interactions between neurons and muscle that regulate intestinal movements (motility). The evidence for this is compelling, and various studies have implicated purine compounds and their receptors as important at virtually every point in the pathways regulating motility, from sensory transduction to neuromuscular transmission.

Despite this evidence, however, identifying the specific sites within the gastrointestinal tract where purine compounds act to regulate motility has been more difficult than might be expected. There are many reasons for this. Purine receptors are found on many different types of cells within the gut. They can be broadly divided into two classes: P1 receptors, for which adenosine is the endogenous ligand, and P2 receptors, which are sensitive to ATP and other nucleotides [1]. Many cells express both P1 and P2 receptors (e.g. compare [2] and [3]), which makes it difficult to discern the parts played by each receptor type. Furthermore, species and regional differences in roles are common, making it difficult to generalise between preparations. This problem is rendered more complex by the presence of ectonucleotidases that can rapidly break down ATP to ADP, AMP or adenosine [1]. Thus, although there is abundant evidence that ATP and adenosine are released from intestinal (enteric) nerve terminals or smooth muscle by a variety of stimuli (for examples [4-12]), the exact mix of ATP, ADP, AMP and adenosine seen by specific 
receptors is almost impossible to determine. This makes the use of subtype-specific antagonists indispensable in order to discriminate the contributions of different receptors and their endogenous ligands. Unfortunately, specific antagonists for many P2 receptors are either unavailable or have only recently come into use.

Several P2Y receptor subtypes have a higher affinity for either UTP or UDP than for either ATP or ADP [1]. Thus, whereas release of uridine nucleotides within the gastrointestinal tract has not been the subject of detailed investigation, it is possible that either UTP or UDP is the endogenous ligand for some P2Y receptors. Although ATP is used throughout this review to designate the probable transmitter as enteric synapses and junctions, the possibility that a uridine nucleotide acts in its place should be kept in mind.

A key issue for considering regulation of intestinal behaviour is the definition of motility itself. Commonly used measures of motility, such as intestinal (or colonic) transit, are the end product of several different motility patterns, making such measures too imprecise to identify the site of action of a drug. Most studies record smoothmuscle contractions in strips or segments but ignore the role of the neural circuitry. However, motility is the end product of the interactions of a complex nervous system (both extrinsic and intrinsic) with myogenic pacemakers [the interstitial cells of Cajal (ICC)] and the two major muscle coats. This review seeks to put the available data into a physiological context to identify current knowledge about the roles of purine nucleosides and purine nucleotides in motility regulation.

\section{Purine receptor subtypes}

The basic properties of purine receptors, their signal transduction mechanisms and their division into P1 (adenosine receptors), $\mathrm{P} 2 \mathrm{X}$ and $\mathrm{P} 2 \mathrm{Y}$ receptors, have been extensively reviewed elsewhere $[1,13,14]$. P1 and P2Y receptors are members of the G-protein-coupled receptor family, and multiple subtypes of each have been cloned. Four subtypes of $\mathrm{P} 1$ receptor have been cloned $\left(\mathrm{A}_{1}, \mathrm{~A}_{2 \mathrm{~A}}\right.$, $A_{2 B}, A_{3}$ ), and specific antagonists are now available for all subtypes [15]. To date, eight subtypes of mammalian P2Y receptors $\left(\mathrm{P}_{2} \mathrm{Y}_{1}, \mathrm{P}_{2} \mathrm{Y}_{2}, \mathrm{P}_{2} \mathrm{Y}_{4}, \mathrm{P}_{2} \mathrm{Y}_{6}, \mathrm{P}_{2} \mathrm{Y}_{11}, \mathrm{P}_{2} \mathrm{Y}_{12}, \mathrm{P} 2 \mathrm{Y}_{13}\right.$, $\mathrm{P} 2 \mathrm{Y}_{14}$ ) have been cloned [13]. Specific antagonists are available for only about half of these receptors [15], which makes analysis of their functions difficult. The P2Y receptors differ in rank order of potency of different nucleotides so that $\mathrm{P} 2 \mathrm{Y}_{1}$ receptors are more sensitive to ADP than they are to ATP, whereas $\mathrm{P}_{2} \mathrm{Y}_{6}$ receptors are most potently activated by UDP, and ATP is either ineffective or an antagonist at other $\mathrm{P} 2 \mathrm{Y}$ receptors (e.g. $\mathrm{P}_{2} \mathrm{Y}_{4}, \mathrm{P}_{2} \mathrm{Y}_{6}, \mathrm{P}_{2} \mathrm{Y}_{14}$ ) [13]. However, knowing the efficacy of exogenous agonists often does not help in understanding the physiological roles of receptors intermingled in a complex system. P2X receptors are ligand-gated cation channels that respond to ATP, although they differ in sensitivity to ATP analogues [1]. Seven different P2X receptor molecules have been cloned $\left(\mathrm{P}_{2} \mathrm{X}_{1}, \mathrm{P} 2 \mathrm{X}_{2}, \ldots\right.$, $\left.\mathrm{P}^{2} \mathrm{X}_{7}\right)$ [1, 14], but some of these can be present as heteromers [14]. Specific antagonists are available for only three of these receptors [15], so they are usually studied using the relatively nonspecific antagonists suramin and pyridoxal phosphate-6-azopheyl-2', 4'-disulphonic acid (PPADS), which also act at some P2Y receptors and can interact with ectonucleotidases [1]. The different receptor subtypes are differentially expressed within the intestinal wall, which is important for consideration of their functions.

\section{Motility patterns}

The end point of gastrointestinal motility is movement of intestinal contents from stomach to anus, but transit is only part of the story and occurs via the interaction of several distinct motility patterns (for reviews see [16-18]). In the small intestine after a meal, these include receptive relaxation $[19,20]$, segmentation $[21,22]$, peristalsis (oral to anal propulsion) and retropulsion [23]. The rate of content transit along the intestine is set by the relative contribution of each pattern [24]. Receptive relaxation occurs when intestinal contents enter a previously empty section of intestine and allows this segment to accommodate the distending material. It limits the distance over which propulsive motor activity can move the intestinal contents. Segmentation makes up more than $90 \%$ of the small intestine contractile activity during digestion and absorption of a meal, with the exact proportion depending on the nutrient content of the meal [22]. It consists of rhythmic localised constrictions that alternate with relaxations [21] and divide and redivide the intestinal contents, mixing luminal content with intestinal secretions (water, bicarbonate, enzymes, bile and mucin), facilitating digestion and nutrient absorption. Although segmentation slowly moves the contents of the lumen anally, about $10 \%$ of contractile activity in the small intestine after a meal involves rapid propulsive contractions that propagate anally over significant distances (peristalsis). In the upper small intestine, orally propagating constrictions that propel content within the duodenum towards the stomach (retrograde peristalsis) are also prominent immediately after a meal [23].

Once digestion is complete, animals enter a fasted state in which a distinctively different motor activity is seen $[16$, 18]. This interdigestive migrating motor complex (MMC) has three distinct phases that migrate slowly along the 
small intestine from the pylorus to the ileocolonic junction (4 $\mathrm{cm} / \mathrm{min}$ upper jejunum, $0.6 \mathrm{~cm} / \mathrm{min}$ distal ileum of humans). Phase I is a period of quiescence that takes up 40$60 \%$ of the complex in humans. This gives way to phase II, a period of irregular contractions that increase in magnitude over $20-30 \%$ of the complex. Phase III is the most prominent component of the MMC and gives it its name. It is a period (5-10\% of the complex) of very strong rhythmic contractions that propagate slowly along the intestine. Phase III contractions are initiated in either the gastric antrum or the proximal duodenum at about the time that the previous phase III contraction reaches the end of the ileum, a cycle duration of 84-112 min in humans.

Motor activity in the colon is largely independent of that in the small intestine and reflects its three primary functions: storage, water recovery and excretion [18]. Receptive relaxation is important for the first; peristalsis or mass-movement contractions or both are the mechanisms for the last. Haustral contractions clearly are relevant in some species (e.g. humans), and retrograde peristalsis is also seen.

These motor patterns are not always readily observed in vitro. However, detailed analyses require such studies. In vitro preparations include isolated segments of otherwise intact small or large intestine; opened segments dissected to expose the mucosa, muscle or enteric neurons; and muscle strips cut either longitudinally or circumferentially. Intact segments are used to study propulsive motor activity, receptive relaxation, propagating contractile complexes such as models of the MMC and, very recently, segmentation. Opened and dissected preparations are used to study simple motility reflexes - ascending excitation, descending inhibition [25] and descending excitation [26]. They are also used to study individual enteric neurons and the locations of functionally identified receptors. Muscle-strip preparations are the most studied and provide information about effects of agonists and antagonists, but this can be hard to translate meaningfully to complex motor patterns.

\section{Neural circuits mediating motility}

The basic control of intestinal motility depends on the activity of the enteric nervous system (ENS), a network of neurons contained entirely within the gastrointestinal wall [16]. Although the ENS is modulated by the central nervous system (CNS), the sympathetic nervous system and hormonal factors, each motor pattern identified above is programmed within the enteric neural circuitry. There have been extensive studies directed at identifying the elements of the enteric circuits, largely focusing on the guinea-pig ileum (for reviews see $[17,27,28]$ ) and recently

Table 1 Functional types of enteric neuron that can be deduced from physiological and anatomical studies

\begin{tabular}{lll}
\hline Basic Function & Plexus & Subtypes in guinea-pig ileum \\
\hline Intrinsic sensory neuron & SMP & AH/Dogiel type II, ChAT/TK-IR, mucosal mechanoreceptor \\
& MP & AH/Dogiel type II, ChAT/calbindin/TK-IR, muscle mechanosensory, chemosensitive \\
Ascending interneuron & MP & AH/Dogiel type II, ChAT/calbindin/TK-IR, anal projection, distension sensitive \\
Descending interneuron & MP & MP, ChAT/calretinin/TK/ENK \\
& MP & NOS/VIP/GRP/ \pm ChAT \\
Excitatory longitudinal muscle motor neuron & MP & ChAT/5-HT, targets myenteric and/or submucosal ganglia \\
Inhibitory longitudinal muscle motor neuron & MP & ChAT/SOM, targets myenteric and/or submucosal ganglia \\
Excitatory circular-muscle motor neuron & ChAT/calretinin/TK & NOS/VIP/GABA, rare in guinea-pig ileum \\
& MP & ChAT/TK, short oral projection \\
Inhibitory circular-muscle motor neuron & ChAT/TK, long oral projection & NOS/VIP/PACAP/ENK, short anal projection \\
Cholinergic secretomotor neuron & MP & NOS/VIP/PACAP/GRP, long anal projection \\
& SMP & ChAT/NPY \\
Noncholinergic secretomotor neuron & MP & ChAT/NPY \\
& SMP & VIP \\
Vasodilator neuron & MP & VIP \\
Intestinofugal neuron & SMP & ChAT/calretinin, cholinergic \\
\hline
\end{tabular}

The subtypes identified come from the guinea-pig ileum, as does the elementary chemical code [17, 27, 28].

$S M P$ submucosal plexus, $M P$ myenteric plexus, ChAT choline acetyltransferase, $T K$ tachykinin, $I R$ immunoreactive, ENK enkephalin, $N O S$ nitric oxide synthase, VIP vasoactive intestine peptide, 5-HT 5-hydroxytryptamine (serotonin), SOM somatostatin, GABA $\gamma$-aminobutyric acid, $P A C A P$ pituitary adenylyl-cyclase-activating peptide, $N P Y$ neuropeptide $\mathrm{Y}$ 
branching out to guinea-pig and mouse colon. At least 11 functionally distinct types of enteric neurons can be identified, and many can be further subdivided according to their neurochemistry, projections or functional specificity (Table 1). For a general review of transmission between functionally identified enteric neurons, see [29]. Studies of ascending excitation and descending inhibition have allowed construction of a basic circuit that accounts for these reflexes (Fig. 1, for review see [17]). Features include feed-forward circuits of orally directed (ascending) interneurons that activate excitatory motor neurons and anally directed (descending) interneurons that activate inhibitory motor neurons. Another key element is a circumferentially organised recurrent network of intrinsic sensory neurons that excite each other [30-32] and have outputs to the ascending and descending feed-forward pathways and to local excitatory and inhibitory motor neurons $[33,34]$. The intrinsic sensory neurons respond to changes in length and tension within the intestinal wall, to mucosal deformation and to mucosal chemical stimulation [33, 34]. A less characterised component of the circuit is an anally directed network that ultimately activates excitatory motor neurons to produce descending excitation $[26,35]$. Although there are differences in the details of this circuit between species and regions [36-40], it provides a broad template for identifying the sites of purine nucleoside and purine nucleotide action in motility regulation.

Four broadly defined targets for adenosine or ATP can be identified within this circuit: sensory transduction, the recurrent network of intrinsic sensory neurons, transmission within the feed-forward pathways and neuromuscular transmission. There is evidence for purinergic involvement in each.

\section{P1 (adenosine) receptors}

Exogenous adenosine and related agonists generally inhibit intestinal motility, depressing peristaltic reflexes and transit in the small and large intestines of rats and guinea pigs $[5,41-46]$. This is largely due to actions on $A_{1}$ receptors. Thus, it might be suggested that endogenous adenosine regulates motility in control intestine. Indeed, $A_{1}$ receptor blockade increases defecation in normal rats [47, 48]. However, neither small intestinal peristalsis nor colonic transit is altered by $A_{1}$ receptor antagonists [45-47], unless the system has been perturbed by a pathological insult. Similarly, peristaltic reflexes in the rat jejunum in vitro, are unaffected by blockade of $A_{1}$ receptors, although they are markedly depressed by activation of these receptors [4143]. On the other hand, blockade of $A_{1}$ receptors restores normal transit in the rat colon in vivo when it has been depressed by either transient ischaemia [45] or as a result of postoperative ileus [46]. How these observations relate to the increased defecation produced by $A_{1}$ blockade is unclear. Furthermore, the roles of adenosine in the major motor activities of the small intestine, segmentation and MMC have not been studied.

Studies of of $\mathrm{A}_{1}$ agonist action sites reveal several mechanisms that can account for their propulsion inhibition. The most obvious is that $\mathrm{A}_{1}$ receptor activation inhibits release of the excitatory transmitter acetylcholine

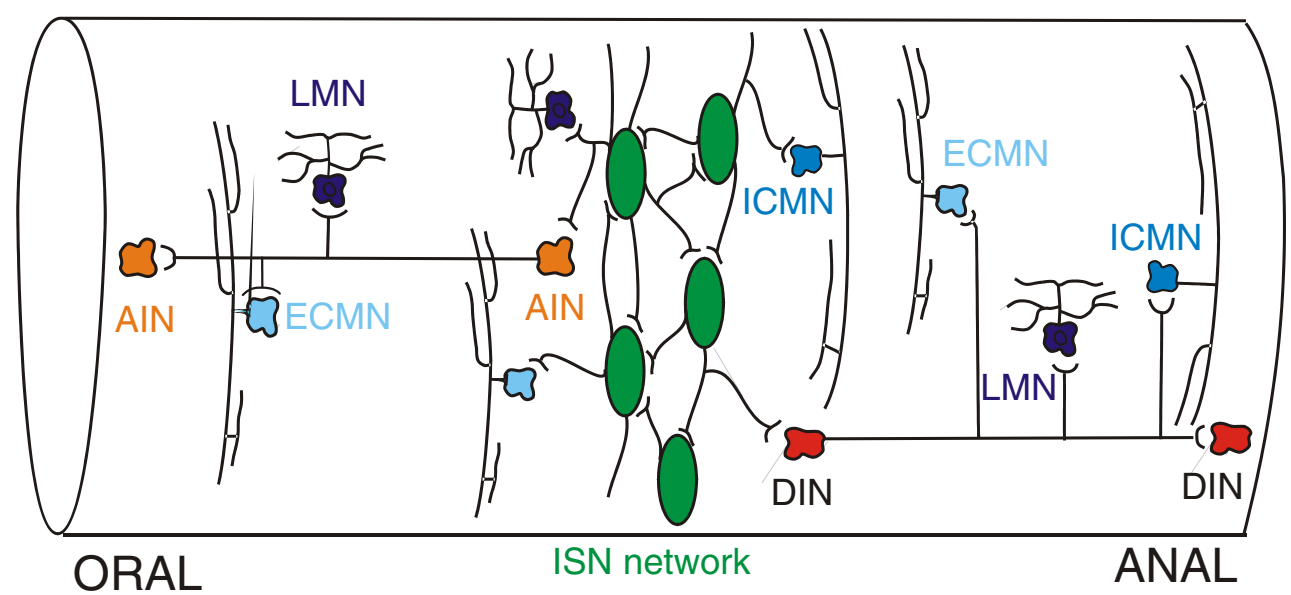

Fig. 1 A basic circuit that accounts for what is known about the mechanisms that produce ascending excitatory and descending inhibitory reflexes in the guinea-pig ileum. Intrinsic sensory neurons (ISN) are shown in green, ascending interneurons (AIN) in orange, excitatory circular-muscle motor neurons (ECMN) in pale blue, longitudinal muscle motor neurons (LMN) in purple, descending interneurons (DIN) in red and inhibitory circular-muscle motor neurons (ICMN) in blue. Inhibitory longitudinal muscle motor neurons are not illustrated, as these are very rare in the guinea-pig ileum. The various populations of descending interneurons are shown as a single population for simplicity 
(ACh) from motor neurons innervating the circular and longitudinal muscles [49-52]. This is supported by a large body of indirect evidence for $\mathrm{A}_{1}$-receptor-mediated inhibition of release from excitatory motor nerve terminals [43, 53-56]. This can clearly account for the abolition of propulsive motor activity by adenosine and $\mathrm{A}_{1}$ agonists. However, other mechanisms are also likely to be important.

Functional studies of $\mathrm{A}_{1}$ receptor locations in pathways that regulate motility (for secretion studies see [57]) have focused on the myenteric plexus intrinsic sensory neurons, neurons with distinctive electrophysiological and morphological properties. Unlike other myenteric neurons, action potentials in these neurons are followed by prolonged afterhyperpolarisations (AHPs), and they usually lack fast excitatory synaptic potentials (EPSPs) but have prominent slow EPSPs (for reviews see [33, 34]). They all have a similar shape; a large, smooth soma with several axons known as Dogiel type II, so they are termed AH/Dogiel type II neurons. Other characteristic features are that axons usually project circumferentially [58] and make synapses

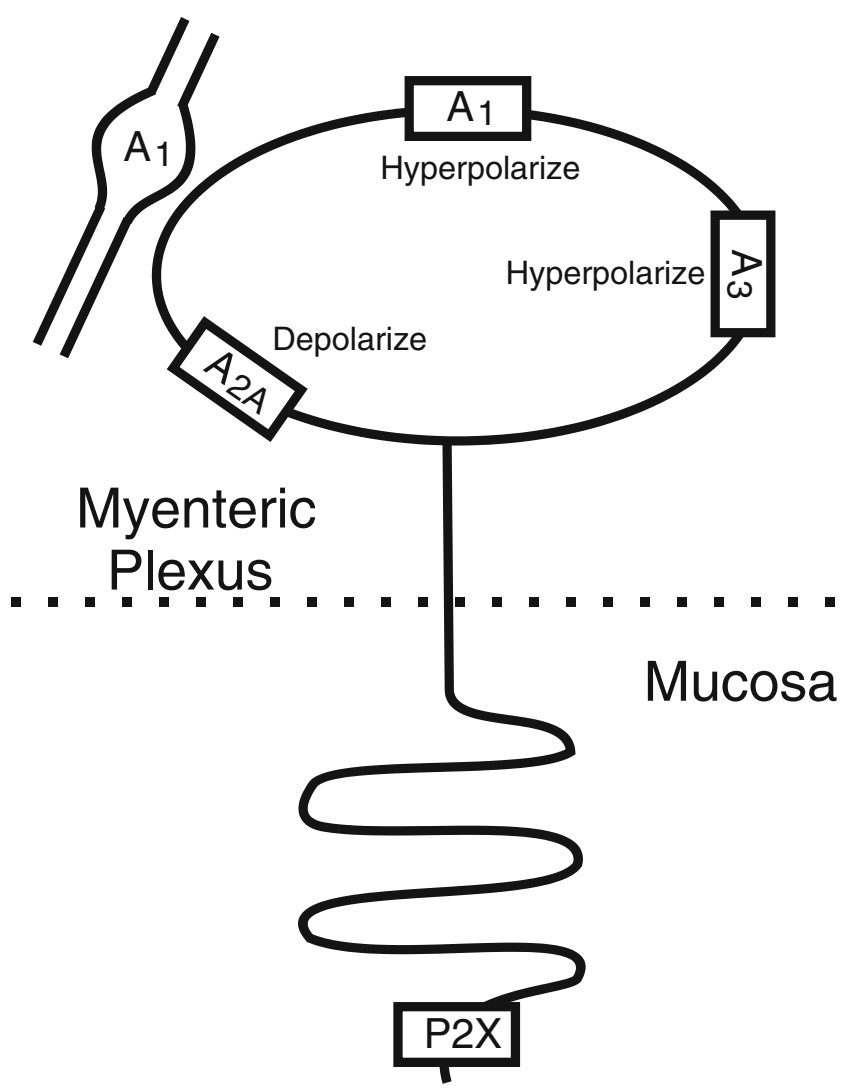

Fig. 2 Functionally identified purinergic receptors in myenteric intrinsic sensory neurons. $\mathrm{A}_{1}, \mathrm{~A}_{2 \mathrm{~A}}$ and $\mathrm{A}_{3}$ receptors are all found on the soma, $A_{1}$ receptors are present on many presynaptic terminals and $\mathrm{P} 2 \mathrm{X}$ receptors appear to be expressed by the mucosal terminals of these neurons. There is also evidence for $\mathrm{P} 2 \mathrm{Y}$ receptors on the soma, but the significance of these is unknown with other AH/Dogiel type II neurons [59, 60]. These neurons express both $\mathrm{P} 1$ and $\mathrm{P} 2$ receptors (Fig. 2). Transmission between them is via slow EPSPs, mediated by tachykinins [61-63]. Importantly, they respond directly to mechanical myenteric plexus deformation $[64,65]$, to increased tension within the intestinal muscle $[66,67]$ and to chemical stimulation of the mucosa [29, 68, 69], indicating that they can act as mechanoreceptive and/or chemoreceptive intrinsic sensory neurons. Because they project circumferentially [58] and excite each other [60], the intrinsic sensory neurons form a recurrent excitatory network. This network can encode ongoing sensory stimuli, with its output depending on neuron excitability, slow EPSP amplitude and AHP magnitude [30, 31]. $\mathrm{A}_{1}$ receptor agonists modify all these parameters. Most AH/Dogiel type II neurons (about 85\%) are hyperpolarised by adenosine, largely through $\mathrm{A}_{1}$ receptors [70], so $\mathrm{A}_{1}$ activation will markedly depress the network's output. Furthermore, $A_{1}$ receptor agonists abolish slow EPSPs evoked in these neurons by electrical stimulation via presynaptic receptors that inhibit transmitter release (Fig. 2) [54]. This would also depress the network's output. Finally, $\mathrm{A}_{1}$ receptor activation enhances AHPs in these neurons [70], which would also suppress firing in the sensory neuron network [30, 31]. These effects would be most prominent under conditions in which the stimulus was slow in onset; for example, during the distensions typically used to evoke propulsive motor activity in isolated intestinal segments. Thus, in addition to reductions in $\mathrm{ACh}$ release from excitatory motor neurons, $\mathrm{A}_{1}$ agonists probably depress activity evoked by sensory stimuli in the enteric neural circuitry.

Presynaptic $A_{1}$ receptors are widely distributed within the ENS. $\mathrm{A}_{1}$ agonists depress fast EPSPs mediated by $\mathrm{ACh}$ in many myenteric neurons other than AH/Dogiel type II neurons but do not depress responses to $\mathrm{ACh}$ in these neurons [54]. This indicates that adenosine has a fourth site of action within enteric pathways that modulate motility. Furthermore, $\mathrm{A}_{1}$ receptor activation depresses tachykinin release from enteric synaptosomes [71] and more intact myenteric networks $[72,73]$, indicating that presynaptic $\mathrm{A}_{1}$ receptors inhibit release of transmitters other than $\mathrm{ACh}$. However, presynaptic $A_{1}$ receptors are not ubiquitous, as $A_{1}$ receptor blockade reveals inhibitory synaptic potentials (IPSPs) in many AH/Dogiel type II neurons [54]. The IPSPs are normally obscured by slow EPSPs [54]. The IPSPs may be mediated by $5-\mathrm{HT}_{1 \mathrm{~A}}$ receptors, because they are blocked by a $5-\mathrm{HT}_{1 \mathrm{~A}}$ antagonist [62]. Thus, whereas many cholinergic nerve terminals in the myenteric plexus have $A_{1}$ receptors, the terminals of serotonin-containing interneurons do not. Nevertheless, that ability of $A_{1}$ agonists to reveal IPSPs in the intrinsic sensory neurons indicates another site at which adenosine can act to depress motility. 
Thus, there are many sites within the enteric neural circuitry where $A_{1}$ receptors and endogenous adenosine may act to modulate motility. However, there is also evidence that $\mathrm{A}_{1}$ receptors may be located on some intestinal smooth muscles [74-77], where they can act to directly inhibit or relax the muscle.

The roles of $A_{2}$ and $A_{3}$ receptors are much less clearly defined that those of $A_{1}$ receptors. Virtually all studies of $A_{2}$ receptor function indicate that activation of these receptors can relax or inhibit contractions of intestinal smooth muscle, largely, if not exclusively, through $\mathrm{A}_{2 \mathrm{~B}}$ receptors. Activation of these receptors relaxes smooth muscle from guinea-pig distal colon [56]; rat duodenum [78], ileum [43] and colon [77]; and mouse distal colon [79]. Various sites of action have been described, including receptors on the smooth muscle [56] and facilitation of the release of NO from inhibitory motor neurons [79]. By contrast, adenosine-mediated relaxation of possum duodenum appears to be via $A_{2 A}$ receptors on the smooth muscle [80]. However, results for $A_{2 A}$ receptors are inconsistent with other data, indicating that they act to facilitate $\mathrm{ACh}$ release in the guinea-pig ileum [53].

There have been no studies of the effects of $\mathrm{A}_{2}$ agonists and antagonists on complex motor patterns. Depolarisations mediated by $\mathrm{A}_{2 \mathrm{~A}}$ receptors have been identified electrophysiologically in a subpopulation of myenteric AH/Dogiel type II neurons from the guinea pig, suggesting that $A_{2 A}$ receptors may act to enhance the output of intrinsic sensory neuron networks [2]. The functions of this subpopulation of sensory neurons have not been identified as yet. $A_{3}$ receptor activation hyperpolarises some AH/Dogiel type II neurons [2], but again, the exact function of these neurons is unknown. Functional roles for the $A_{2}$ subtypes and the $A_{3}$ subtype will only be determined when the cellular locations and effects on complex motor patterns have been fully investigated. As yet, the only real evidence is that $A_{3}$ receptors have been localised to neurons immunoreactive for substance $\mathrm{P}$ in the human submucosal plexus [81], which suggests that these receptors may be important in enteric sensory pathways. However, no data are available about a similar localisation in equivalent myenteric neurons.

\section{P2 receptors}

The literature on the roles of $\mathrm{P} 1$ receptors in the gastrointestinal tract is relatively limited, but the literature on $\mathrm{P} 2$ receptors is vast. This is largely because of the many studies testing whether ATP or a related purine nucleotide mediates inhibitory neuromuscular transmission in the gut (for review see [82]). There is also substantial literature directed at identifying the roles of $\mathrm{P} 2$ receptors in transmission between enteric neurons (reviewed by [14,
83, 84] and elsewhere in this issue). However, whereas recent immunohistochemical studies show that $\mathrm{P} 2$ receptors are found at many sites within the gut, the roles of these receptors in motility regulation are enigmatic. This section will focus on the various functional roles for P2 receptors and hence for purine nucleotides highlighting P2X and P2Y receptors as necessary.

\section{Inhibitory neuromuscular transmission}

It is widely accepted that ATP is important for transmission from enteric inhibitory motor neurons to the intestinal smooth muscle $[82,85,86]$. Activation of these neurons produces a rapid hyperpolarisation of the smooth-muscle membrane, an inhibitory junction potential (IJP), often followed by a smaller, but more prolonged, hyperpolarisation (for some representative papers see [87-93]). Inhibitory motor neuron activation relaxes intestinal smooth muscle [86, 92, 94], and this relaxation is markedly reduced IJP blockade in some preparations (for examples see [95-98]). The inhibitory motor neurons contain nitric oxide synthase (NOS) [99], and blockade of this enzyme prevents the prolonged hyperpolarisations and depresses smooth-muscle relaxation, but not the IJPs, evoked by their activity $[87,90$, 93, 98, 100]. The IJPs are blocked by the bee venom toxin apamin, an antagonist of the SK form of calcium-dependent potassium channels $[95,96,101]$.

Evidence that ATP mediates IJPs in intestinal smooth muscle is extensive and includes observations that ATP hyperpolarises intestinal smooth muscle [102, 103], an effect blocked by apamin $[95,96]$ and by the broadspectrum P2 receptor antagonist suramin [104, 105]. However, this evidence has been fraught with problems. For example, in the guinea-pig taenia caeci, hyperpolarisation evoked by pituitary adenylyl-cyclase-activating peptide, which is contained in many inhibitory motor neurons, is blocked by apamin and depressed by suramin [106-108]. In the dog colon, both the IJP and the slow hyperpolarisation evoked by inhibitory nerve stimulation are abolished by inhibition of NOS [109-111], leaving no place for an ATP-mediated component of inhibitory transmission. Similarly, studies of inhibitory neuromuscular transmission that measure relaxation often lead to the conclusion that either NO or vasoactive intestinal peptide (VIP) (see [82, 85]), each of which is released by inhibitory motor neurons, are the major mediators. NO can produce relaxation independently of changes in membrane potential [112], so measures of membrane potential and relaxation may not produce equivalent results. The problem is compounded because the commonly used broad spectrum antagonist PPADS is not very effective at blocking electrically evoked IJPs in circular muscle of either guinea-pig ileum or colon [39, 113]. Nevertheless, recent data obtained using specific 
antagonists for and structural localisation of $\mathrm{P}_{2} \mathrm{Y}_{1}$ receptors place this hypothesis on a more secure footing (for review see [114]). In human and mouse intestine, IJPs and the associated relaxations are blocked by the $\mathrm{P}_{2} \mathrm{Y}_{1}$ receptor antagonist MRS 2179 [92, 98]. Furthermore, immunoreactivity for the $\mathrm{P} 2 \mathrm{Y}_{1}$ receptor protein is located on the smooth muscle in both species [92, 115]. Together with the knowledge that enteric nerve stimulation releases ATP and its metabolites (see above), these data are compelling evidence that ATP acting at $\mathrm{P}_{2} \mathrm{Y}_{1}$ receptors mediates IJPs evoked by activity in intrinsic inhibitory motor neurons.

Whereas IJPs are probably mediated by $\mathrm{P}_{2} \mathrm{Y}_{1}$ receptors, the cellular location of these receptors is less clear. Neuromuscular transmission in the intestine appears to be an indirect process, with neurotransmitters acting on ICC, which then couple to the smooth muscle via gap junctions. The evidence for this is compelling for both ACh and NO (reviewed by [116]). But it is less clear that purinergic neuromuscular transmission requires ICC as intermediates

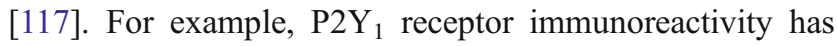
been localised to human smooth-muscle cells [92], whereas $\mathrm{P}^{2} \mathrm{Y}_{1}$ mRNA is seen in ICC of small intestine from mice and humans [118]. Furthermore, whereas NO-mediated responses of murine intestine disappear when ICC are absent, IJPs can still be recorded in the same tissues [119]. Perhaps IJPs are mediated by both direct action of ATP on smooth-muscle P2Y receptors and via ICC.

\section{Functional roles of purinergic IJPs}

IJPs are the most prominent electrophysiological response to inhibitory nerve activity, so they would be expected to play a major role in intestinal motility regulation. However, studies of the purinergic component of inhibitory neuromuscular transmission and regulation of the major intestinal motor patterns have been ambiguous. These studies have used apamin to block IJPs, because most precede the availability of specific $\mathrm{P} 2 \mathrm{Y}_{1}$ antagonists and because broadspectrum blockers of $\mathrm{P} 2$ receptors can act within the enteric circuits themselves (see below and [120]). Indeed, both suramin and PPADS can block ectonucleotidases [121], making interpretation of results more difficult.

Receptive relaxation of the ileum depends on activity in inhibitory motor neurons but is unaffected by concentrations of apamin that abolish IJPs [19, 122]. By contrast, NOS blockade abolishes receptive relaxation [19, 122]. Thus, although IJPs must have been evoked by the inhibitory neural activity underlying receptive relaxation, they play little role in the behaviour itself.

Studies with apamin on roles for IJPs in propulsive contraction generation and propagation triggered by saline distension have yielded contrasting results, with reports that the threshold for propulsion initiation is either reduced
[123] or unaffected by apamin [124]. By contrast, threshold is clearly reduced when NOS activity is inhibited [123, 124]. However, apamin increases the pressure produced during propulsive contractions and reveals localised circularmuscle contractions that do not propagate along the intestine [124]. When apamin is combined with NOS inhibition, the anally propagating contractions are converted to apparently uncoordinated contractions at many sites along the segment [122-124]. Saline distension is a distributed stimulus activating intrinsic sensory neurons all along the intestinal segment. Thus, the muscle would receive converging excitatory and inhibitory input from ascending and descending pathways, and blocking IJPs would allow the excitation to predominate, thereby leading to the uncoordinated activity.

Localised distension or mucosal deformation also leads to anally propagating contractions of the longitudinal and circular muscle in guinea-pig ileum $[26,35,125,126]$ and colon, descending excitation [127]. In the colon, the descending excitation is preceded by a descending relaxation that is depressed by apamin, indicating that it depends, in part, on IJPs, presumably resulting from ATP release [127]. The apamin-resistant component is abolished by NOS inhibition, so the relaxation depends on both purinergic and nitrergic transmission [127]. In contrast, no descending relaxation is seen in the ileum [26], but apamin increases the amplitude and rate of rise of the descending contractions [26]. Electrophysiological studies of guineapig ileum in which contractile activity is blocked show that distension and mucosal stimulation evoke prominent apamin-sensitive IJPs, but not excitatory junction potentials (EJPs), in the circular-muscle anal to the stimulus [128130]. It appears that purinergic IJPs slow and limit the size of descending contractions but do not relax the muscle itself. Similar results have recently been obtained by combining extracellular recording from the circular smooth muscle with video-imaging contractile activity during anally propagating propulsive contractions [131]. EJP/ action potential complexes associated with propulsive contractions were not preceded by IJPs, although small, spontaneous IJPs were readily detected. Thus, the roles of IJPs in the ileum and colon are distinctively different. Purinergic neuromuscular transmission in the ileum limits the excitation resulting from EJPs, whereas in the colon, it also helps set the muscle tension, even in the absence of excitatory input.

There have been very few studies of the effects of inhibiting IJPs on the two most prominent motor behaviours of the intestine: MMCs and segmentation. Each has been difficult to characterise in vitro. However, recent developments allow some conclusions to be drawn. Isolated mouse intestine and colon exhibit periodic strong contraction complexes that propagate along the segment in a 
manner analogous to phase III contractions of interdigestive MMCs [132-135]. This similarity is so strong that the colonic propagating contraction complexes are usually termed colonic MMCs, although they may actually be analogues of mass-movement contractions involved in defecation. Whereas IJPs are seen in the mouse colon, apamin does not affect colonic MMC cycling frequency or propagation speeds and has inconsistent effects on contraction amplitude [132, 136, 137].

Development of methods for constructing contractile activity maps as functions of time and length along the intestine from video recordings of isolated intestinal segments [138] has allowed analysis of nutrient-induced segmentation in guinea-pig small intestine [131]. This manifests as episodes of contractile activity evoked by either fatty acids or amino acids in the intestinal lumen. Several motility patterns are seen, but the most prominent consists of rhythmic stationary contractions confined to narrow regions: segmentation. Large numbers of small apamin-sensitive IJPs are recorded between contraction episodes [131], indicating ongoing activity of inhibitory motor neurons along the length of the segment. Interestingly, large apamin-sensitive IJPs are time-locked to the stationary contractions on both the oral and anal sides outside the contracting region during episodes [131]. This suggests that IJPs limit the spread of contractions, perhaps by preventing propagation of smooth-muscle action potentials from the excited region.

Nutrient-induced motor activity also includes circularmuscle constrictions that propagate slowly for short distances orally or anally [139]. Like the stationary contractions, these short-length propagating contractions may be limited by large apamin-sensitive IJPs that are seen just beyond the point at which the contraction disappears [131]. It seems IJPs also limit the propagation speed of these contractions, as blocking IJPs converts much of the contractile activity induced by luminal nutrients to constrictions that propagate rapidly along the entire segment [131].

Overall, IJPs mediated by ATP in the ileum appear to limit the spread and efficacy of excitatory input to the muscle rather than to relax it, as in the colon. Relaxation is the province of $\mathrm{NO}$ released from the same neurons.

\section{P2X receptors within the muscle}

Both $\mathrm{P} 2 \mathrm{X}_{2}$ and $\mathrm{P} 2 \mathrm{X}_{5}$ receptors have been identified immunohistochemically on ICC from mouse and guinea pig [140], which raises a question as to their roles. Intestinal smooth muscle is often excited by $\mathrm{P} 2 \mathrm{X}$ receptor activation [115], so receptors on ICC may be important. Furthermore, some ICCs are pacemakers for the smooth muscle, driving slow waves that set the underlying rhythm for motor activity (for review see [141]). P2X receptor activation modifies pacemaker activity in some ICCs [142], so these receptors may regulate intestinal pacemakers. However, P2X receptors are also found in both canine and murine colonic smooth-muscle cells [115, 143], which are contracted by $\mathrm{P} 2 \mathrm{X}$ stimulation. There has been no analysis of muscle or ICC P2X receptor involvement in intestinal motor patterns.

\section{P2 receptors within enteric neural circuits}

There is excellent evidence that $\mathrm{P} 2$ receptors play important roles within the ENS. Fast EPSPs mediated by P2X receptors are seen in both myenteric and submucosal neurons (see [120]), and there is strong evidence for synaptic potentials mediated by $\mathrm{P}_{2} \mathrm{Y}_{1}$ receptors in submucosal neurons [144, 145]. This section deals with myenteric receptor location and how they fit into the neural circuits mediating different motor reflexes.

In guinea-pig ileum, $\mathrm{P} 2 \mathrm{X}$ receptors have been identified immunohistochemically in three classes of myenteric neurons, each with its own distinct set of functions. The AH/Dogiel type II neurons express immunoreactivity for $\mathrm{P}_{2} \mathrm{X}_{2}$ [3] and $\mathrm{P} 2 \mathrm{X}_{7}$ receptors [146]. Ascending interneurons express immunoreactivity for $\mathrm{P}_{2} \mathrm{X}_{3}$ receptors $[147,148]$. Most NOS neurons express immunoreactivity for $\mathrm{P} 2 \mathrm{X}_{2}$ receptors [3], and a subset also express $\mathrm{P}_{2} \mathrm{X}_{3}$ receptors $[147,148]$. NOS neurons are either inhibitory motor neurons or descending interneurons [99]. Analysis of P2X receptor distribution amongst functionally identified classes of neurons in other species is more limited, because knowledge of the functions of immunohistochemically identified neuronal subtypes is less complete. Nevertheless, some information is available. A key point is that $\mathrm{P} 2 \mathrm{X}_{1}$ receptors have not been identified in enteric neurons in any species studied. On the other hand, $\mathrm{P} 2 \mathrm{X}_{2}$ receptors are expressed in some mouse myenteric neurons [115, 149], although their neurochemistry has not been identified. $\mathrm{P} 2 \mathrm{X}_{2}$ receptors are also found in a minority of rat calretinin immunoreactive myenteric neurons and in a subset of calbindin immunoreactive neurons in the same preparation [150]. In the rat, many calretinin neurons have Dogiel type II morphology, and neurons with this morphology have the electrophysiological properties of $\mathrm{AH}$ neurons [151], as they do in both guinea pig and mouse [64, 152]. Thus, some AH/Dogiel type II neurons in the rat myenteric plexus probably express $\mathrm{P} 2 \mathrm{X}_{2}$ receptors. Many more apparently express $\mathrm{P}_{2} \mathrm{X}_{3}$ receptors, as about $80 \%$ of calretinin neurons in the rat ileal myenteric plexus are $\mathrm{P} 2 \mathrm{X}_{3}$ receptor immunoreactive [150]. The functions of $\mathrm{P} 2 \mathrm{X}$ receptors in $\mathrm{AH} /$ Dogiel type II neurons are discussed below. P2X receptors are widespread in submucosal neurons of mouse but are largely localised to axons in the myenteric plexus [153]. 
P2Y receptors have also been found immunohistochemically on neurochemically identified enteric neurons. In guinea pig, virtually all calbindin, and thus AH/Dogiel type II, myenteric neurons express $\mathrm{P} 2 \mathrm{Y}_{12}$ but not $\mathrm{P} 2 \mathrm{Y}_{6}$ or $\mathrm{P} 2 \mathrm{Y}_{2}$ receptors [154]. On the other hand, some calretinin neurons express $\mathrm{P} 2 \mathrm{Y}_{2}$ receptors and/or $\mathrm{P}_{2} \mathrm{Y}_{6}$ receptors, and a subpopulation of NOS neurons express $\mathrm{P}_{2} \mathrm{Y}_{6}$ receptors [154]. The functions of these receptors are unclear, as the only evidence about roles for $\mathrm{P} 2 \mathrm{Y}$ receptors in motility regulation suggests that $\mathrm{P} 2 \mathrm{Y}_{1}$ receptors are the major contributors (see below). Whereas reverse transcriptase polymerase chain reaction (RT-PCR) shows that $\mathrm{P}_{2} \mathrm{Y}_{1}$ receptors are expressed in the guinea-pig submucosa [155], the available antisera against this receptor subtype have yet to reveal neurons in either the myenteric or submucosal plexuses of guinea pigs.

By contrast, $\mathrm{P} 2 \mathrm{Y}_{1}$ receptors have been identified in myenteric neurons in both human and mouse [92, 115] and submucous neurons in mouse and rat $[115,156]$. In mice, $\mathrm{P} 2 \mathrm{Y}_{1}$ receptors are seen in many but not all myenteric neurons immunoreactive for NOS, although these neurons do not account for all $\mathrm{P} 2 \mathrm{Y}_{1}$ immunoreactive myenteric neurons.

\section{Neural P2X receptors and motility}

P2X receptors mediate fast EPSPs in some myenteric neurons (see [84, 120, 157]). To identify their physiological roles, it has been necessary to control for effects of broaderspectrum antagonists on inhibitory neuromuscular transmission. Two strategies have evolved to identify at least some roles of neural P2X receptors. First, PPADS has been used as the antagonist in several studies of motility reflexes

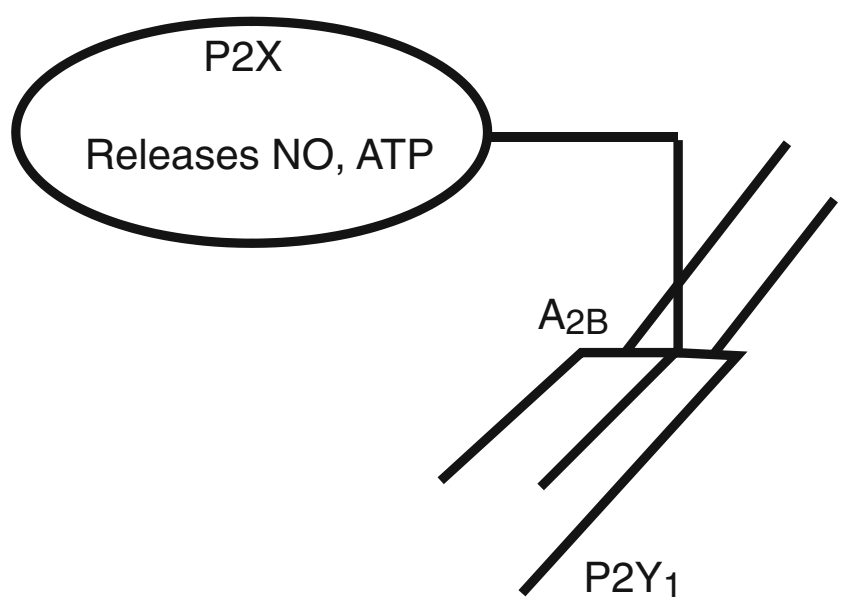

Fig. 3 Purinergic receptors and their relationships to inhibitory motor neurons supplying the circular muscle. These neurons are excited by descending interneurons via P2X receptors, release ATP to act on $\mathrm{P} 2 \mathrm{Y}_{1}$ receptors within the circular muscle and also release nitric oxide (NO). NO release is facilitated by $A_{2 B}$ receptors and motor patterns. PPADS depresses IJPs in guinea-pig circular muscle [39, 113] but only at concentrations higher than needed to block purinergic fast EPSPs in myenteric neurons [158]. This may be because PPADS is relatively ineffective in blocking $\mathrm{P} 2 \mathrm{Y}_{1}$ receptors negatively coupled to adenylyl cyclase [1]. Second, these studies have used divided organ baths that allow separate superfusion of different parts of reflex pathways running along the intestine $[113,159]$. The results show that in guinea-pig ileum, P2X receptors mediate transmission from descending interneurons to inhibitory motor neurons (Fig. 3) but not transmission between interneurons or from intrinsic sensory neurons to interneurons [113]. Inhibitory motor neurons are all immunoreactive for NOS [99], and $90 \%$ of all NOS neurons in this preparation express $\mathrm{P} 2 \mathrm{X}_{2}$ receptors [3], indicating that this receptor subtype mediates this form of transmission. However, some NOS neurons express $\mathrm{P}_{2} \mathrm{X}_{3}$ receptors $[147,148]$, so a $\mathrm{P}_{2} \mathrm{X}_{2.3}$ heteromer may be involved.

$\mathrm{P} 2 \mathrm{X}$ receptors may also play a role in transmission between descending interneurons in the descending excitatory reflex pathway (Fig. 4). PPADS depresses descending excitation of both longitudinal and circular muscle, but blocking $5-\mathrm{HT}_{3}$ receptors depresses descending excitation in circular muscle only [35]. Blockade of nicotinic receptors has no effect on these reflexes in either muscle layer. Combined blockade of $\mathrm{P} 2 \mathrm{X}$ and $5-\mathrm{HT}_{3}$ receptors has no greater effect on descending excitation of the circular muscle than blockade of either receptor alone, suggesting that the two are acting in series. Anatomical studies indicate that excitatory circular-muscle motor neurons but not longitudinal muscle motor neurons receive synaptic input

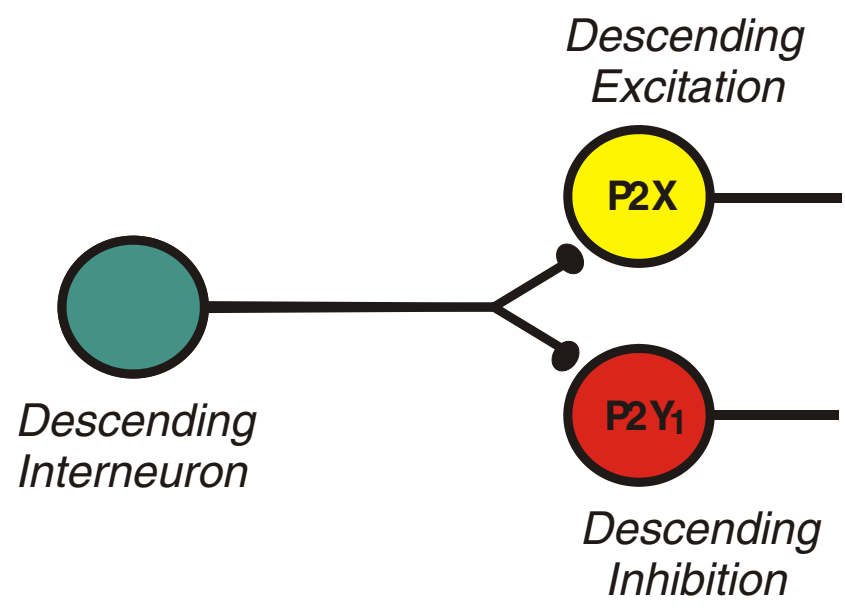

Fig. 4 Different P2 receptors have independent roles in transmission between interneurons in two descending reflex pathways. P2X receptors are important for transmission to interneurons of the descending excitatory pathway (yellow), whereas $\mathrm{P}_{2} \mathrm{Y}_{1}$ receptors are important for transmission between interneurons of the descending inhibitory pathway (red) 
from 5-HT-containing descending interneurons [160], suggesting that this is where the $5-\mathrm{HT}_{3}$ receptors act. Thus, the simplest explanation for the data is that PPADS blocks transmission from descending interneurons to two types of interneurons, including 5-HT-containing interneurons (Fig. 4). This is supported by a divided organ bath study, which found that PPADS depressed descending excitatory reflexes when in a chamber where it would act on synapses between interneurons but not on the muscle [125].

A surprising conclusion from these studies is that P2X receptors have no major role in ascending reflex pathways $[159,161]$ or in transmission to longitudinal muscle motor neurons [35]. This is despite the fact that $\mathrm{P}_{2} \mathrm{X}_{3}$ receptors are found in calretinin-immunoreactive neurons of guineapig ileum [147, 148], which are either ascending interneurons or longitudinal muscle motor neurons [99].

Whereas these studies of simple reflexes indicate that P2X receptors are important, studies of more complex motor patterns using PPADS to identify P2X involvement have been disappointing. PPADS does not alter the threshold of propulsive reflex activation by saline distension [35], nor does it change the motor activity induced by luminal nutrients in the guinea-pig small intestine [139]. A reduction in threshold for initiation of propulsion by PPADS that was antagonised by suramin has also been reported [162]. This may have been due to the interactions with ectonucleotidases of these antagonists [121] rather than effects on P2 receptors. Thus, it is not yet clear how the involvement of $\mathrm{P} 2 \mathrm{X}$ receptors in simple reflexes is translated into more complex behaviours.

Two studies have addressed the role of the $\mathrm{P} 2 \mathrm{X}$ receptors in complex behaviours using mice in which either $\mathrm{P} 2 \mathrm{X}_{2}$ or $\mathrm{P}_{2} \mathrm{X}_{3}$ receptors were knocked out. Knockout of the $\mathrm{P} 2 \mathrm{X}_{2}$ receptor depressed propulsive reflexes evoked by saline distension and eliminated P2-mediated fast EPSPs in myenteric neurons, although responses to ATP and $\alpha, \beta-$ methylene ATP (an agonist at $\mathrm{P}_{2} \mathrm{X}_{3}$ receptors) were preserved in AH/Dogiel type II neurons [149]. On the other hand, intestinal transit of a radioactive marker was normal in the knockout mice. Knockout of the $\mathrm{P}_{2} \mathrm{X}_{3}$ receptor also depressed propulsive reflexes evoked by saline distension, with no effect on intestinal transit, and this was associated with depressed sensitivity of AH/Dogiel type II neurons to $\alpha, \beta$-methylene ATP [163]. These results highlight two significant issues for interpreting the available data. First, although AH/Dogiel type II neurons in guinea pig and mouse appear functionally identical [164], they may express different $\mathrm{P} 2 \mathrm{X}$ receptor subtypes with $\mathrm{P} 2 \mathrm{X}_{2}$ in the former and $\mathrm{P}_{2} \mathrm{X}_{3}$ in the latter. Thus, species differences may be critical. Second, different measures of motility can give very different results, even when they appear to be measuring the same thing - in this case, the mechanisms that propel content along the gut. As yet, there have been no studies of either segmentation or the MMC using P2X receptor knockouts.

Whereas there is strong evidence for a role for P2X receptors in descending reflexes in guinea-pig ileum, identical experiments in guinea-pig and rat colon provide no evidence for such a role $[39,40]$. This is despite electrophysiological evidence for P2X-receptor-mediated EPSPs in the guinea-pig colon at least $[158,165]$.

\section{Neural P2Y receptors and motility}

There have been almost no studies of the roles of neural $\mathrm{P} 2 \mathrm{Y}$ receptors in motility reflexes, although more is known about the involvement of such receptors in reflex control of secretion. However, distension evokes slow EPSPs that trigger action potentials in NOS descending interneurons but not in other myenteric neurons [166]. The distensionevoked slow EPSPs arise from descending interneurons and are blocked by PPADS at higher concentrations than needed to abolish P2X-mediated fast EPSPs [167]. This higher concentration of PPADS depresses transmission along the descending inhibitory pathway when added to the interneuron chamber of a divided organ bath, but lower concentrations of PPADS that block fast EPSPs have no effect [167]. Descending inhibition depression is mimicked by a $\mathrm{P}_{2} \mathrm{Y}_{1}$ receptor antagonist (McMillan \& Gwynne, unpublished). Thus, $\mathrm{P}_{2} \mathrm{Y}_{1}$ receptors may mediate transmission between interneurons in the descending inhibitory pathway via slow EPSPs. As yet, roles for other P2Y receptors located on enteric neurons have not been identified, and there are no published studies of neural P2Y receptors on complex motility patterns.

\section{Sensory transduction}

The presence of $\mathrm{P} 2 \mathrm{X}$ receptors within intrinsic sensory neurons suggests they are involved in sensory transduction [168], and recent data support this idea. ATP applied to mucosal villi of the guinea-pig ileum evokes bursts of action potentials in nearby myenteric AH/Dogiel type II neurons [169]. The ATP-evoked bursts of action potentials mimic the effect of mucosally applied 5-HT and low pH. Some amino acids have a similar effect, and this is depressed by PPADS [29]. Both mucosal application of amino acids and mucosal application of ATP evoke local inhibitory reflexes in the circular muscle, and each is depressed by PPADS [170]. The wider physiological significance of these observations for motility regulation has not been tested, but chemical stimuli, such as nutrients, may act in part by the release of ATP from intestinal epithelial cells.

There is also evidence suggesting a role for $\mathrm{P}_{2} \mathrm{Y}_{1}$ receptors in sensory transduction within the intestinal wall. A subepithelial layer of fibroblasts in the rat intestinal 
mucosa expresses $\mathrm{P}_{2} \mathrm{Y}_{1}$ receptors and releases ATP to act back on these receptors in response to mechanical deformation [171]. There is evidence indicating that mechanical deformation of the mucosa releases 5-HT [172-174] and that this is the primary mechanism of sensory transduction for this stimulus. However, the possibility of a significant role for $\mathrm{P}_{2} \mathrm{Y}_{1}$ receptors remains to be tested.

Roles of enteric glial cells

Whereas the roles of $\mathrm{P} 1$ and $\mathrm{P} 2$ receptors on neurons and in the muscle layers are the focus of this review, P2X and P2Y receptors have been identified on enteric glial cells [175177]. Roles of glia in neural signalling elsewhere in the nervous system have become topics of major interest and are the subject of many studies in the CNS (for recent reviews see [178-180]). Thus, it is reasonable to assume that enteric glia play a role in purinergic signalling within the ENS. Indeed, there is evidence that networks of enteric glia can generate propagating waves of intracellular $\mathrm{Ca}^{2+}$ that pass via gap junctions throughout the networks and that this depends on ATP release [181]. Furthermore, enteric glia express an extracellular surface-bound ectonucleotidase [182], so that they will be important in the regulation of ATP levels following release from nerve terminals or other glia. Also, reductions in enteric glia have been correlated with some motility disturbances [183, 184]. However, how glial P2 receptors, $\mathrm{Ca}^{2+}$ waves or glial ectonucleotidases fit into the regulation of intestinal motility is unclear, and there is no evidence as to the part they play in the circuitry responsible for any given motor pattern. This can be expected to be an important issue for investigation as mechanisms of glial signalling to neurons are clarified.

\section{Where to from here?}

There is no doubt that ATP and its metabolites play signalling roles within the gastrointestinal tract and hence in motility regulation. The difficulty has been in defining the physiological and pathophysiological conditions under which they act. This problem has been similar for many other compounds found to act as either neurotransmitters or modulators within the intestine. For example, although tachykinin-mediated slow EPSPs are prominent in many enteric neurons [61, 62] and simple motility reflexes are altered by specific tachykinin antagonists $[185,186]$, it has been very difficult to show a role for neural tachykinin receptors in normal motility patterns. It seems likely that many of the effects of these relatively enigmatic transmitters and modulators will be seen only in pathological circumstances, as with the $A_{1}$ receptor involvement in the postoperative ileus. If so, then identifying appropriate model systems will be crucial for understanding the roles of these compounds. An important issue here is to examine the actions of specific antagonists for the different P1 and P2 receptor subclasses on motility patterns other than propulsive reflexes. The major motor activities of the small intestine are segmentation in the fed state and the MMC in the fasted state, but neither has been studied in sufficient detail to identify roles for either $\mathrm{P} 1$ or $\mathrm{P} 2$ receptors. In vitro model systems for both behaviours are now becoming available, and analysing the roles of ATP and adenosine, in particular, in these models should finally begin to identify their significance for intestinal behaviour.

Acknowledgements This work was supported by project grants (299807, 40053) from the National Health and Medical Research Council (Australia)

\section{References}

1. Ralevic V, Burnstock G (1998) Receptors for purines and pyrimidines. Pharmacol Rev 50:413-492

2. Christofi FL (2001) Unlocking mysteries of gut sensory transmission: is adenosine the key? News Physiol Sci 16:201207

3. Castelucci P, Robbins HL, Poole DP et al (2002) The distribution of purine $\mathrm{P} 2 \mathrm{X}(2)$ receptors in the guinea-pig enteric nervous system. Histochem Cell Biol 117:415-422

4. McConalogue K, Todorov L, Furness JB et al (1996) Direct measurement of the release of ATP and its major metabolites from the nerve fibres of the guinea-pig taenia coli. Clin Exp Pharmacol Physiol 23:807-812

5. Shinozuka K, Maeda T, Hayashi E (1985) Possibilities for adenosine modulation of peristaltic reflex in guinea pig isolated ileum. J Pharmacobiodyn 8:877

6. Katsuragi T, Matsuo K, Sato C et al (1996) Non-neuronal release of ATP and inositol 1,4,5-trisphosphate accumulation evoked by P2- and M-receptor stimulation in guinea pig ileal segments. J Pharmac Exp Ther 277:747-752

7. Katsuragi T, Soejima O, Tokunaga T et al (1992) Evidence for postjunctional release of ATP evoked by stimulation of muscarinic receptors in ileal longitudinal muscles of guinea pig. J Pharmac Exp Ther 260:1309-1313

8. Hammond JR, MacDonald WF, White TD (1988) Evoked secretion of $\left[{ }^{3} \mathrm{H}\right]$ noradrenaline and ATP from nerve varicosities isolated from the myenteric plexus of the guinea pig ileum. Can J Physiol Pharmacol 66:369-375

9. White TD (1984) Characteristics of neuronal release of ATP. Prog Neuropsychopharmacol Biol Psychiat 8:487-493

10. Al-Humayyd M, White TD (1985) 5-hydroxytryptamine releases adenosine 5 'triphosphate from nerve varicosities isolated from the myenteric plexus of guinea-pig ileum. Br J Pharmacol 84:2734

11. White TD (1982) Release of ATP from isolated myenteric varicosities by nicotinic agonists. Eur J Pharmacol 79:333-334

12. White TD, Leslie RA (1982) Depolarization-induced release of adenosine 5-triphosphate from isolated varicosities derived from the myenteric plexus of the guinea pig small intestine. J Neurosci 2:206-215

13. Abbracchio MP, Burnstock G, Boeynaems J-M et al (2006) International union of pharmacology LVIII: update on the P2Y G 
protein-coupled nucleotide receptors: from molecular mechanisms and pathophysiology to therapy. Pharmacol Rev 58:281341

14. North RA (2002) Molecular physiology of P2X receptors. Physiol Rev 82:1013-1067

15. Alexander SPH, Mathie A, Peters JA (2006) Guide to receptors and channels, 2nd edn. Br J Pharmacol 147(Suppl 3):S1-S180

16. Furness JB (2005) The enteric nervous system, 2nd edn. Blackwell, Oxford

17. Bornstein JC, Furness JB, Kunze WAA et al (2002) Enteric reflexes that influence motility. In Brookes SJH, Costa M (eds) Innervation of the gastrointestinal tract. Taylor \& Francis, London

18. Hasler WL (2003) Motility of the small intestine and colon. In Yamada T (ed) Textbook of gastroenterology, 4th edn. Lippincott Williams \& Wilkins, Philadelphia

19. Waterman SA, Costa M, Tonini M (1994) Accommodation mediated by enteric inhibitory reflexes in the isolated guinea-pig small intestine. J Physiol (Lond) 474:539-546

20. Tonini M, Vicini R, Cervio E et al (2005) 5- $\mathrm{HT}_{7}$ receptors modulate peristalsis and accommodation in the guinea pig ileum. Gastroenterology 129:1557-1566

21. Cannon WB (1912) Peristalsis, segmentation and the myenteric reflex. Am J Physiol 30:114-128

22. Schemann M, Ehrlein HJ (1986) Postprandial patterns of canine jejunal motility and transit of luminal content. Gastroenterology 90:991-1000

23. Andrews JM, Doran SM, Hebbard GS et al (2001) Nutrientinduced spatial patterning of human duodenal motor function. Am J Physiol 280:G501-G509

24. Schemann M, Ehrlein HJ, Sahyoun H (1985) Computerised method for pattern recognition of intestinal motility: functional significance of the spread of contractions. Med Biol Eng Comput 23:143-149

25. Bayliss WM, Starling EH (1899) The movements and innervation of the small intestine. J Physiol (Lond) 24:99-143

26. Spencer N, Walsh M, Smith TK (1999) Does the guinea-pig ileum obey the 'law of the intestine'? J Physiol (Lond) 517:889898

27. Brookes SJH, Costa M (2002) Cellular organisation of the mammalian enteric nervous system. In Brookes $\mathrm{SJH}$, Costa $\mathrm{M}$ (eds) Innervation of the gastrointestinal tract. Taylor \& Francis, London

28. Brookes SJH (2001) Classes of enteric nerve cells in the guineapig small intestine. Anat Rec 262:58-70

29. Gwynne RM, Bornstein JC (2007) Synaptic transmission at functionally identified synapses in the enteric nervous system: roles for both ionotropic and metabotropic receptors. Curr Neuropharmac 5:1-17

30. Thomas EA, Bertrand PP, Bornstein JC (2000) A computer simulation of recurrent, excitatory networks of sensory neurons of the gut in guinea-pig. Neurosci Lett 287:137-140

31. Thomas EA, Bornstein JC (2003) Inhibitory cotransmission or after hyperpolarizing potentials can regulate firing in recurrent networks with excitatory metabotropic transmission. Neuroscience 120:333-351

32. Thomas EA, Sjövall H, Bornstein JC (2004) Computational model of the migrating motor complex of the small intestine. Am J Physiol Gastrointest Liver Physiol 286:G564-G572

33. Furness JB, Kunze WAA, Bertrand PP et al (1997) Intrinsic primary afferent neurons of the intestine. Prog Neurobiol 53:118

34. Furness JB, Jones C, Nurgali K et al (2004) Intrinsic primary afferent neurons and nerve circuits within the intestine. Prog Neurobiol 72:143-164
35. Monro RL, Bertrand PP, Bornstein JC (2002) ATP and 5-HT are the principal neurotransmitters in the descending excitatory reflex pathway of the guinea-pig ileum. Neurogastro Mot 14:255-264

36. Messenger JP, Furness JB (1990) Projections of chemicallyspecified neurons in the guinea-pig colon. Arch Histol Cytol $53: 467-495$

37. Messenger JP (1993) Immunohistochemical analysis of neurons in the proximal colon of the guinea-pig. Arch Histol Cytol $56: 459-474$

38. Clerc N, Furness JB, Li ZS et al (1998) Morphological and immunohistochemical identification of neurons and their targets in the guinea-pig duodenum. Neuroscience 86:679-694

39. Bian X-C, Heffer LF, Gwynne RM et al (2004) Synaptic transmission in simple motility reflex pathways excited by distension in guinea pig distal colon. Am J Physiol Gastrointest Liver Physiol 287:G1017-G1027

40. Bian X-C, Bornstein JC, Bertrand PP (2003) Nicotinic transmission at functionally distinct synapses in descending reflex pathways of the rat colon. Neurogastro Mot 15:161-171

41. Coupar IM, Hancock DL (1994) The adenosine agonist NECA inhibits intestinal secretion and peristalsis. J Pharm Pharmac 46:801-804

42. Hancock DL, Coupar IM (1995) Functional characterization of the adenosine receptor mediating inhibition of peristalsis in the rat jejunum. Br J Pharmacol, 115:739-744

43. Coupar IM (1999) Characterization and tissue location of the neural adenosine receptor in the rat ileum. Br J Pharmacol 126:1269-1275

44. Poli E, Pozzoli C (1997) Histamine $\mathrm{H}_{3}$ receptors do not modulate reflex-evoked peristaltic motility in the isolated guinea-pig ileum. Eur J Pharmacol 327:49-56

45. Kadowaki M, Tokita K, Nagakura Y et al (2000) Adenosine $A_{1}$ receptor blockade reverses dysmotility induced by ischemiareperfusion in rat colon. Eur J Pharmacol 409:319-323

46. Kadowaki M, Nagakura Y, Tokita K et al (2003) Adenosine $A_{1}$ receptor blockade reverses experimental postoperative ileus in rat colon. Eur J Pharmacol 458:197-200

47. Suzuki M, Tomaru A, Kishibayashi N et al (1995) Effects of the adenosine $\mathrm{A}_{1}$-receptor antagonist on defecation, small intestinal propulsion and gastric emptying in rats. Jap J Pharmacol 68:119 123

48. Tomaru A, Ishii A, Kishibayashi $\mathrm{N}$ et al (1994) Possible physiological role of endogenous adenosine in defecation in rats. Eur J Pharmacol 264:91-94

49. Lee JJ, Talubmook C, Parsons ME (2001) Activation of presynaptic A1-receptors by endogenous adenosine inhibits acetylcholine release in the guinea-pig ileum. J Auton Pharmacol 21:29-38

50. Nitahara K, Kittel A, Liang SD et al (1985) A1-receptormediated effect of adenosine on the release of acetylcholine from the myenteric plexus: role and localization of ecto-ATPase and 5'-nucleotidase. Neuroscience 67:159-168

51. Somogyi GT, Vizi ES (1988) Evidence that cholinergic axon terminals are equipped with both muscarinic and adenosine receptors. Brain Res Bull 21:575-579

52. Alberts P (1989) Effects of $N^{6}, 2^{\prime}-O$-dibutyryladenosine $3^{\prime}, 5^{\prime}$ cyclic monophosphate, adenosine, and of oxotremorine and 3 isobutyl- 1-methylxanthine on the electrically evoked $\left[{ }^{3} \mathrm{H}\right]$ acetylcholine secretion in the guinea-pig ileum myenteric plexus. Acta Physiol Scand 137:489-496

53. Tomaru A, Ina Y, Kishibayashi N, Karasawa A (1995) Excitation and inhibition via adenosine receptors of the twitch response to electrical stimulation in isolated guinea pig ileum. Jap J Pharmacol 69:429-433 
54. Christofi FL, Wood JD (1993) Presynaptic inhibition by adenosine A1 receptors on guinea pig small intestinal myenteric neurons. Gastroenterology 104:1420-1429

55. De Man JG, Seerden TC, De Winter BY et al (2003) Alteration of the purinergic modulation of enteric neurotransmission in the mouse ileum during chronic intestinal inflammation. $\mathrm{Br} \mathrm{J}$ Pharmacol 139:172-184

56. Kadowaki M, Takeda M, Tokita K et al (2000) Molecular identification and pharmacological characterization of adenosine receptors in the guinea-pig colon. Br J Pharmacol 129:871-876

57. Christofi FL (2007) Purinergic receptors and gastrointestinal secretomotor function. Purinergic Signalling (in press)

58. Bornstein JC, Hendriks R, Furness JB et al (1991) Ramifications of the axons of AH-neurons injected with the intracellular marker biocytin in the myenteric plexus of the guinea pig small intestine. J Comp Neurol 314:437-451

59. Pompolo S, Furness JB (1988) Ultrastructure and synaptic relationships of calbindin- reactive, Dogiel type II neurons, in myenteric ganglia of guinea-pig small intestine. J Neurocytol 17:771-782

60. Kunze WAA, Furness JB, Bornstein JC (1993) Simultaneous intracellular recordings from enteric neurons reveals that myenteric AH neurons transmit via slow excitatory post-synaptic potentials. Neuroscience 55:685-694

61. Alex G, Kunze WAA, Furness JB et al (2001) Comparison of the effects of neurokinin-3 receptor blockade on two forms of slow synaptic transmission in myenteric $\mathrm{AH}$ neurons. Neuroscience 104:263-269

62. Johnson PJ, Bornstein JC (2004) Neurokinin-1 and -3 receptor blockade inhibits slow excitatory synaptic transmission in myenteric neurons and reveals slow inhibitory input. Neuroscience 126:137-147

63. Neunlist M, Dobreva G, Schemann M (1999) Characteristics of mucosally projecting myenteric neurones in the guinea-pig proximal colon. J Physiol (Lond) 517:533-546

64. Mao Y, Wang B, Kunze W (2006) Characterization of myenteric sensory neurons in the mouse small intestine. J Neurophysiol 96:998-1010

65. Kunze WAA, Clerc N, Furness JB et al (2000) The soma and neurites of primary afferent neurons in the guinea-pig intestine respond differentially to deformation. J Physiol (Lond) 526:375385

66. Kunze WAA, Clerc N, Bertrand PP et al (1999) Contractile activity in intestinal muscle evokes action potential discharge in guinea-pig myenteric neurons. J Physiol (Lond) 517:547-561

67. Kunze WAA, Furness JB, Bertrand PP et al (1998) Intracellular recording from myenteric neurons of the guinea-pig ileum that respond to stretch. J Physiol (Lond) 506:827-842

68. Kunze WAA, Bornstein JC, Furness JB (1995) Physiological identification of sensory nerve cells in a peripheral organ (the intestine) of a mammal. Neuroscience 66:1-4

69. Bertrand PP, Kunze WAA, Bornstein JC et al (1997) Analysis of the responses of myenteric neurons in the small intestine to chemical stimulation of the mucosa. Am J Physiol 273:G422G435

70. Christofi FL, Wood JD (1994) Electrophysiological subtypes of inhibitory $\mathrm{P} 1$ purinoceptors on myenteric neurones of guinea-pig small bowel. Br J Pharmacol 113:703-710

71. Christofi FL, McDonald TJ, Cook MA (1990) Adenosine receptors are coupled negatively to release of tachykinin(s) from enteric nerve endings. J Pharmac Exp Ther 253:290-295

72. Broad RM, McDonald TJ, Brodin E et al (1992) Adenosine A1 receptors mediate inhibition of tachykinin release from perifused enteric nerve endings. Am J Physiol 262:G525-G531
73. Moneta NA, McDonald TJ, Cook MA (1997) Endogenous adenosine inhibits evoked substance $\mathrm{P}$ release from perifused networks of myenteric ganglia. Am J Physiol 272:G38-G45

74. Nicholls J, Hourani SMO (1997) Characterization of adenosine receptors on rat ileum, ileal longitudinal muscle and muscularis mucosae. Eur J Pharmacol 338:143-150

75. Bailey SJ, Hourani SMO (1990) A study of the purinoceptors mediating contraction in the rat colon. Br J Pharmacol 100:753756

76. Bailey SJ, Hickman D, Hourani SMO (1992) Characterization of the P1-purinoceptors mediating contraction of the rat colon muscularis mucosae. Br J Pharmacol 105:400-404

77. Bailey SJ, Hourani SMO (1992) Effects of purines on the longitudinal muscle of the rat colon. Br J Pharmacol 105:885-892

78. Peachey JA, Hourani SMO, Kitchen I (1996) Differential development of adenosine $A_{1}$ and $A_{2 b}$ receptors in the rat duodenum. Br J Pharmacol 119:949-958

79. Zizzo MG, Mulè F, Serio R (2006) Inhibitory responses to exogenous adenosine in murine proximal and distal colon. Br J Pharmacol 148:956-963

80. Woods CM, Toouli J, Saccone GTP (2003) $\mathrm{A}_{2 \mathrm{~A}}$ and $\mathrm{A}_{3}$ receptors mediate the adenosine-induced relaxation in spontaneously active possum duodenum in vitro. Br J Pharmacol 138:1333-1339

81. Christofi FL, Zhang H, Yu J-G (2001) Differential gene expression of adenosine $\mathrm{A} 1, \mathrm{~A} 2 \mathrm{a}, \mathrm{A} 2 \mathrm{~b}$, and $\mathrm{A} 3$ receptors in the human enteric nervous system. J Comp Neurol 439:46-64

82. Kuriyama H, Kitamura K, Itoh $\mathrm{T}$ et al (1998) Physiological features of visceral smooth muscle cells, with special reference to receptors and ion channels. Physiol Rev 78:811-920

83. Galligan JJ, LePard KJ, Schneider DA et al (2000) Multiple mechanisms of fast excitatory synaptic transmission in the enteric nervous system. J Auton Nerv Syst 81:97-103

84. Galligan JJ, North RA (2004) Pharmacology and function of nicotinic acetylcholine and $\mathrm{P} 2 \mathrm{X}$ receptors in the enteric nervous system. Neurogastro Mot 16(Suppl 1):64-70

85. Bornstein JC, Costa M, Grider JR (2004) Enteric motor and interneuronal circuits controlling motility. Neurogastro Mot 16 (Suppl 1):34-38

86. Hoyle CHV, Milner P, Burnstock G (2002) Neuroeffector transmission in the intestine. In: Brookes SJH, Costa M (eds) Innervation of the gastrointestinal tract. Taylor \& Francis, London

87. Lyster DJ, Bywater RAR, Taylor GS (1992) Effects of a nitric oxide synthase inhibitor on non-cholinergic junction potentials in the circular muscle of the guinea-pig ileum. J Auton Nerv Syst 41:187-196

88. Crist JR, He XD (1991) Noncholinergic membrane potential responses to transmural nerve stimulation in the guinea pig ileum. Am J Physiol 260:G240-G249

89. Bridgewater M, Cunnane TC, Brading AF (1995) Characteristic features of inhibitory junction potentials evoked by single stimuli in the guinea-pig isolated taenia caeci. J Physiol (Lond) 485: $145-155$

90. Spencer NJ, Bywater RAR, Holman ME et al (1998) Spontaneous and evoked inhibitory junction potentials in the circular muscle layer of mouse colon. J Auton Nerv Syst 69:115-121

91. Crist JR, He XD, Goyal RK (1992) Both ATP and the peptide VIP are inhibitory neurotransmitters in guinea- pig ileum circular muscle. J Physiol (Lond) 447:119-131

92. Gallego D, Hernández P, Clavé P (2006) P2 $Y_{1}$ receptors mediate inhibitory purinergic neuromuscular transmission in the human colon. Am J Physiol Gastrointest Liver Physiol 291:G584-G594

93. Hirst GDS, Bywater RAR, Teramoto N et al (2004) An analysis of inhibitory junction potentials in the guinea-pig proximal colon. J Physiol (Lond) 558:841-855 
94. Benkó R, Undi S, Wolf M et al (2006) P2 purinoceptors account for the non-nitrergic NANC relaxation in the rat ileum. N S Arch Pharmacol 373:153-162

95. Maas AJJ, Den Hartog A, Ras R et al (1980) The action of apamin on guinea-pig taenia coli. Eur J Pharmacol 67:265274

96. Den Hertog A, Pielkenrood J, Van den Akker J (1985) Responses evoked by electrical stimulation, adenosine triphosphate, adenosine and 4-aminopyridine in taenia caeci of the guinea-pig. Eur J Pharmacol 109:373-380

97. Fernandez E, Guo X, Vergara P et al (1998) Evidence supporting a role for ATP as non-adrenergic non-cholinergic inhibitory transmitter in the porcine ileum. Life Sci 62:1303-1315

98. De Man JG, De Winter BY, Seerden TC et al (2003) Functional evidence that ATP or a related purine is an inhibitory NANC neurotransmitter in the mouse jejunum: study on the identity of P2X and P2Y purinoceptors involved. Br J Pharmacol 140:1108-1116

99. Costa M, Brookes SJH, Steele PA et al (1996) Neurochemical classification of myenteric neurons in the guinea-pig ileum. Neuroscience 75:949-967

100. He XD, Goyal RK (1993) Nitric oxide involvement in the peptide VIP-associated inhibitory junction potential in the guinea-pig ileum. J Physiol (Lond) 461:485-499

101. Den Hertog A, Pielkenrood J, Van den Akker J (1985) Effector mechanisms for alpha,beta-methylene ATP and ATP derivatives in guinea-pig taenia caeci. Eur J Pharmacol 110:95-101

102. Tomita T, Watanabe H (1973) A comparison of the effects of adenosine triphosphate with noradrenaline and with the inhibitory potential of the guinea-pig taenia coli. J Physiol (Lond) 231:167-177

103. Jager LP (1974) The effect of catecholamines and ATP on the smooth muscle cell membrane of the guinea-pig taenia coli. Eur J Pharmacol 25:372-382

104. Hoyle CHV, Knight GE, Burnstock G (1990) Suramin antagonizes responses to $\mathrm{P}_{2}$-purinoceptor agonists and purinergic nerve stimulation in the guinea-pig urinary bladder and taenia coli. Br J Pharmacol 99:617-621

105. Den Hertog A, Nelemans A, Van den Akker J (1989) The inhibitory action of suramin on the $\mathrm{P}_{2}$-purinoceptor response in smooth muscle cells of guinea-pig taenia caeci. Eur J Pharmacol 166:531-534

106. McConalogue K, Lyster DK, Furness JB (1995) Electrophysiological analysis of the actions of pituitary adenylyl cyclase activating peptide in the taenia of the guinea-pig caecum. N S Arch Pharmacol 352:538-544

107. Portbury AL, McConalogue K, Furness JB et al (1995) Distribution of pituitary anedylyl cyclase activating peptide (PACAP) immunoreactivity in neurons of the guinea-pig digestive tract and their projections in the ileum and colon. Cell Tiss Res 279:385-392

108. McConalogue K, Furness JB, Vremec MA (1995) Histochemical, pharmacological, biochemical and chromatographic evidence that pituitary adenylyl cyclase activating peptide is involved in inhibitory neurotransmission in the taenia of the guinea-pig caecum. J Auton Nerv Syst 50:311-322

109. Thornbury KD, Ward SM, Dalziel HH et al (1991) Nitric oxide and nitrosocysteine mimic nonadrenergic, noncholinergic hyperpolarization in canine proximal colon. Am J Physiol 261:553557

110. Dalziel HH, Thornbury KD, Ward SM et al (1991) Involvement of nitric oxide synthetic pathway in inhibitory junction potentials in canine proximal colon. Am J Physiol 260:789-792

111. Ward SM, Dalziel HH, Thornbury KD et al (1992) Nonadrenergic, noncholinergic inhibition and rebound excitation in canine colon depend on nitric oxide. Am J Physiol 262:G237G243
112. Kwon S-C, Ozaki H, Karaki H (2000) NO donor sodium nitroprusside inhibits excitation-contraction coupling in guinea pig taenia coli. Am J Physiol 279:G1235-G1241

113. Bian X-C, Bertrand PP, Bornstein JC (2000) Descending inhibitory reflexes involve $\mathrm{P} 2 \mathrm{X}$ receptor-mediated transmission from interneurons to motor neurons in guinea-pig ileum. J Physiol (Lond) 528:551-560

114. Wood JD (2006) The enteric purinergic $\mathrm{P}_{2} \mathrm{Y}_{1}$ receptor. Curr Opin Pharmacol 6:564-570

115. Giaroni C, Knight GE, Ruan H-Z et al (2002) P2 receptors in the murine gastrointestinal tract. Neuropharmacology 43:1313-1323

116. Ward SM, Sanders KM, Hirst GDS (2004) Role of interstitial cells of Cajal in neural control of gastrointestinal smooth muscles. Neurogastro Mot 16(Suppl 1):112-117

117. Huizinga JD, Berezin I, Daniel EE et al (1990) Inhibitory innervation of colonic smooth muscle cells and interstitial cells of Cajal. Can J Physiol Pharmacol 68:447-454

118. Chen H, Redelman D, Ro S et al. Selective labeling and isolation of functional classes of interstitial cells of Cajal of the human and murine small intestine. Am J Physiol Cell Physiol 292:C497C507

119. Ward SM, McLaren GJ, Sanders KM (2006) Interstitial cells of Cajal in the deep muscular plexus mediate enteric motor neurotransmission in the mouse small intestine. J Physiol (Lond) 573:147-159

120. Bertrand PP, Ren J (2007) Purinergic receptors and synaptic transmission in enteric neurons. Purinergic Signalling (in press)

121. Bültmann R, Trendelenburg M, Tuluc F et al (1999) Concomitant blockade of P2X-receptors and ecto-nucleotidases by P2receptor antagonists: functional consequences in rat vas deferens. N S Arch Pharmacol 359:339-344

122. Ciccocioppo R, Onori L, Messori E et al (1994) Role of nitric oxide-dependent and -independent mechanisms in peristalsis and accomodation in the rabbit distal colon. J Pharmac Exp Ther 270:929-937

123. Holzer P, Lippe IT, Tabrizi AL (1997) Dual excitatory and inhibitory effect of nitric oxide on peristalsis in the guinea pig intestine. J Pharmac Exp Ther 280:154-161

124. Waterman SA, Costa M (1994) The role of enteric inhibitory motoneurons in peristalsis in the isolated guinea-pig small intestine. J Physiol (Lond) 477:459-468

125. Spencer NJ, Walsh M, Smith TK (2000) Purinergic and cholinergic neuro-neuronal transmission underlying reflexes activated by mucosal stimulation in the isolated guinea-pig ileum. J Physiol (Lond) 522:321-331

126. Spencer NJ, Smith CB, Smith TK (2001) Role of muscle tone in peristalsis in guinea-pig small intestine. J Physiol (Lond) 530:295-306

127. Smith TK, Robertson WJ (1998) Synchronous movements of the longitudinal and circular muscle during peristalsis in the isolated guinea-pig distal colon. J Physiol (Lond) 506:563577

128. Smith TK, Furness JB (1988) Reflex changes in circular muscle activity elicited by stroking the mucosa: An electrophysiological analysis in the isolated guinea-pig. J Auton Nerv Syst 25:205218

129. Smith TK, Bornstein JC, Furness JB (1990) Distension-evoked ascending and descending reflexes in the circular muscle of guinea-pig ileum: an intracellular study. J Auton Nerv Syst 29:203-213

130. Smith TK, Bornstein JC, Furness JB (1991) Interactions between reflexes evoked by distension and mucosal stimulation: electrophysiological studies of guinea-pig ileum. J Auton Nerv Syst 34:69-76

131. Gwynne RM, Bornstein JC (2007) Mechanisms underlying nutrient induced segmentation in isolated guinea-pig small 
intestine. Am J Physiol Gastrointest Liver Physiol 292:G1162G1172

132. Lyster DJK, Bywater RAR, Taylor GS (1995) Neurogenic control of myoelectric complexes in the mouse isolated colon. Gastroenterology 108:1371-1378

133. Fida R, Lyster DJK, Bywater RAR et al (1997) Colonic migrating motor complexes (CMMCs) in the isolated mouse colon. Neurogastro Mot 9:99-107

134. Bush TG, Spencer NJ, Watters N et al (2001) Effects of alosetron on spontaneous migrating motor complexes in murine small and large bowel in vitro. Am J Physiol 281:G974-G983

135. Abdu F, Hicks GA, Hennig G et al (2002) Somatostatin $s^{2} t_{2}$ receptors inhibit peristalsis in the rat and mouse jejunum. Am J Physiol 282:G624-G633

136. Spencer NJ, Bywater RAR, Taylor GS (1998) Disinhibition during myoelectric complexes in the mouse colon. J Auton Nerv Syst 71:37-47

137. Brierley SM, Nichols K, Grasby DJ et al (2001) Neural mechanisms underlying migrating motor complex formation in mouse isolated colon. Br J Pharmacol 132:507-517

138. Hennig GW, Costa M, Chen BG et al (1999) Quantitative analysis of peristalsis in the guinea-pig small intestine using spatio-temporal maps. J Physiol (Lond) 517:575-590

139. Gwynne RM, Thomas EA, Goh SM (2004) Segmentation induced by intraluminal fatty acid in isolated guinea-pig duodenum and jejunum. J Physiol (Lond) 556:557-569

140. Burnstock G, Lavin S (2002) Interstitial cells of Cajal and purinergic signalling. Auton Neurosci 97:68-72

141. Sanders KM, Koh SD, Ward SM (2006) Interstitial cells of Cajal as pacemakers in the gastrointestinal tract. Ann Rev Physiol 68:307-343

142. Furuzono S, Nakayama S, Imaizumi Y (2005) Purinergic modulation of pacemaker $\mathrm{Ca}^{2+}$ activity in interstitial cells of Cajal. Neuropharmacology 48:264-273

143. Lee HK, Ro S, Kim YH (2005) Differential expression of P2Xpurinoceptor subtypes in circular and longitudinal muscle of canine colon. Neurogastro Mot 17:575-584

144. Hu H-Z, Gao N, Zhu MX et al (2003) Slow excitatory synaptic transmission mediated by $\mathrm{P}_{2} \mathrm{Y}_{1}$ receptors in the guinea-pig enteric nervous system. J Physiol (Lond) 550:493-504

145. Monro RL, Bertrand PP, Bornstein JC (2004) ATP participates in three excitatory post-synaptic potentials in the submucous plexus of the guinea pig ileum. J Physiol (Lond) 556:571-584

146. Hu H-Z, Gao N, Lin Z et al (2007) P2X7 receptors in the enteric nervous system of guinea-pig small intestine. J Comp Neurol 440:299-310

147. Poole DP, Castelucci P, Robbins HL et al (2002) The distribution of $\mathrm{P} 2 \mathrm{X} 3$ purine receptor subunits in the guinea pig enteric nervous system. Auton Neurosci 101:39-47

148. Van Nassauw L, Brouns I, Adriaensen D et al (2002) Neurochemical identification of enteric neurons expressing $\mathrm{P} 2 \mathrm{X}_{3}$ receptors in the guinea-pig ileum. Histochem Cell Biol 118:193-203

149. Ren J, Bian X-C, DeVries $M$ et al (2003) $P 2 X_{2}$ subunits contribute to fast synaptic excitation in myenteric neurons of the mouse small intestine. J Physiol (Lond) 552:809-821

150. Xiang Z, Burnstock G (2004) P2X2 and P2X3 purinoceptors in the rat enteric nervous system. Histochem Cell Biol 121:169179

151. Browning KN, Lees GM (1996) Myenteric neurons of the rat descending colon: electrophysiological and correlated morphological properties. Neuroscience 73:1029-1047

152. Bornstein JC, Furness JB, Kunze WAA (1994) Electrophysiological characterization of myenteric neurons, how do classification schemes relate? J Auton Nerv Syst 48:1-15
153. Ruan H-Z, Burnstock G (2005) The distribution of P2X 5 purinergic receptors in the enteric nervous system of mouse. Cell Tiss Res 319:191-200

154. Xiang Z, Burnstock G (2006) Distribution of P2Y(6) and P2Y (12) receptor: their colocalization with calbindin, calretinin and nitric oxide synthase in the guinea pig enteric nervous system. Histochem Cell Biol 125:327-336

155. Gao N, Hu H-Z, Zhu MX et al (2006) The P2Y1 purinergic receptor expressed by enteric neurones in guinea-pig intestine. Neurogastro Mot 18:316-323

156. Christofi FL, Wunderlich J, Yu JG et al (2004) Mechanically evoked reflex electrogenic chloride secretion in rat distal colon is triggered by endogenous nucleotides acting at P2Y1, P2Y2, and P2Y4 receptors. J Comp Neurol 469:16-36

157. Galligan JJ (2002) Pharmacology of synaptic transmission in the enteric nervous system. Curr Opin Pharmacol 2:623-629

158. LePard KJ, Messori E, Galligan JJ (1997) Purinergic fast excitatory postsynaptic potentials in myenteric neurons of guinea pig: distribution and pharmacology. Gastroenterology 113:15221534

159. Johnson PJ, Shum OR, Thornton PDJ et al (1999) Evidence that inhibitory motor neurons of the guinea-pig small intestine exhibit fast excitatory synaptic potentials mediated via $\mathrm{P}_{2 \mathrm{x}}$ receptors. Neurosci Lett 266:169-172

160. Neal KB, Bornstein JC (2007) Mapping serotonin inputs to enteric neurons of the guinea pig small intestine. Neuroscience 145:556-567

161. LePard KJ, Galligan JJ (1999) Analysis of fast synaptic pathways in myenteric plexus of guinea pig ileum. Am J Physiol 276:G529-G538

162. Heinemann A, Shahbazian A, Barthó L (1999) Different receptors mediating the inhibitory action of exogenous ATP and endogenously released purines on guinea-pig intestinal peristalsis. Br J Pharmacol 128:313-320

163. Bian X-C, Ren J, DeVries AL et al (2003) Peristalsis is impaired in the small intestine of mice lacking the P2X3 subunit. J Physiol (Lond) 551:309-322

164. Bornstein JC (2006) Intrinsic sensory neurons of mouse guttoward a detailed knowledge of enteric neural circuitry across species. Focus on "characterization of myenteric sensory neurons in the mouse small intestine". J Neurophysiol 96:973974

165. Nurgali K, Furness JB, Stebbing MJ (2003) Analysis of purinergic and cholinergic fast synaptic transmission to identified myenteric neurons. Neuroscience 116:335-347

166. Thornton PDJ, Bornstein JC (2002) Slow excitatory synaptic potentials evoked by distension in myenteric descending interneurons of guinea-pig ileum. J Physiol (Lond) 539:589602

167. Bornstein JC, Thornton PDJ, Gwynne RM (2002) ATP acting on $\mathrm{P}_{2 \mathrm{Y}}$ receptors mediates synaptic transmission between interneurons of the descending inhibitory reflex pathway in the guinea pig ileum. Gastroenterology 122:A-8

168. Bertrand PP (2003) ATP and sensory transduction in the enteric nervous system. Neuroscientist 9:243-260

169. Bertrand PP, Bornstein JC (2002) ATP as a putative sensory mediator: activation of intrinsic sensory neurons of the myenteric plexus via P2X receptors. J Neurosci 22:4767-4775

170. Gwynne RM, Bornstein JC (2007) Local inhibitory reflexes excited by mucosal application of nutrient amino acids in guineapig jejunum. Am J Physiol Gastrointest Liver Physiol 292: G1660-G1670

171. Furuya K, Sokabe M, Furuya S (2005) Characteristics of subepithelial fibroblasts as a mechano-sensor in the intestine: cell-shape-dependent ATP release and P2Y1 signaling. J Cell Sci 118:3289-3304 
172. Kirchgessner AL, Tamir H, Gershon MD (1992) Identification and stimulation by serotonin of intrinsic sensory neurons of the submucosal plexus of the guinea pig gut: activity-induced expression of Fos immunoreactivity. J Neurosci 12:235-248

173. Kirchgessner AL, Liu M-T, Gershon MD (1996) In situ identification and visualization of neurons that mediate enteric and enteropancreatic reflexes. J Comp Neurol 371:270-286

174. Pan H, Gershon MD (2000) Activation of intrinsic afferent pathways in submucosal ganglia of the guinea pig small intestine. J Neurosci 20:3295-3309

175. Vanderwinden J-M, Timmermans J-P, Schiffmann SN (2003) Glial cells, but not interstitial cells, express P2X7, an ionotropic purinergic receptor, in rat gastrointestinal musculature. Cell Tiss Res 312:149-154

176. Van Nassauw L, Costagliola A, Van Op den Bosch J et al (2006) Region-specific distribution of the P2Y4 receptor in enteric glial cells and interstitial cells of Cajal within the guinea-pig gastrointestinal tract. Auton Neurosci 126-127:299306

177. Rühl A (2005) Glial cells in the gut. Neurogastro Mot 17:777790

178. Allen NJ, Barres BA (2005) Signalling between glia and neurons: focus on synaptic plasticity. Curr Opin Neurobiol 15:542-548
179. Paukert M, Bergles DE (2006) Synaptic communication between neurons and $\mathrm{NG}^{+}$cells. Curr Opin Neurobiol 16:515-521

180. Fields RD, Burnstock G (2006) Purinergic signalling in neuron glia interactions. Nature Rev Neurosci 7:423-436

181. Zhang W, Segura BJ, Lin TR et al (2003) Intercellular calcium waves in cultured enteric glia from neonatal guinea pig. Glia 42:252-262

182. Braun N, Sévigny J, Robson SC et al (2004) Association of the ecto-ATPase NTPDase 2 with glial cells of the peripheral nervous system. Glia 45:124-132

183. Aubé A-C, Cabaroccas J, Bauer J (2006) Changes in enteric neurone phenotype and intestinal functions in a transgenic mouse model of enteric glia disruption. Gut 55:630-637

184. Nasser Y, Fernandez E, Keenan CM (2006) Role of enteric glia in intestinal physiology: effects of the gliotoxin fluorocitrate on motor and secretory function. Am J Physiol Gastrointest Liver Physiol 291:G912-G927

185. Johnson PJ, Bornstein JC, Burcher E (1998) Roles of neuronal $\mathrm{NK}_{1}$ and $\mathrm{NK}_{3}$ receptors in synaptic transmission during motility reflexes in the guinea-pig ileum. Br J Pharmacol 124:1375-1384

186. Johnson PJ, Yuan SY, Bornstein JC et al (1996) Analysis of contributions of acetylcholine and tachykinins to neuro-neuronal transmission in motility reflexes in the guinea-pig ileum. Br J Pharmacol 118:973-983 